\title{
MANAGEMENT CONTROL SYSTEMS AND FIRM SUSTAINABILITY: EVIDENCE FROM TEXTILE AND APPAREL BUSINESSES IN THAILAND
}

\author{
Phaprukbaramee Ussahawanitchakit \\ Mahasarakham Business School, Mahasarakham University Kantarawichai, \\ Mahasarakham 44150, Thailand \\ E-mail: markarlington@hotmail.com
}

Published online: 29 December 2017

To cite this article: Ussahawanitchakit, P. (2017). Management control systems and firm sustainability: Evidence from textile and apparel businesses in Thailand. Asian Academy of Management Journal, 22(2), 185-208. https://doi.org/10.21315/aamj2017.22.2.7

To link to this article: https://doi.org/10.21315/aamj2017.22.2.7

\begin{abstract}
The objective of this study is to examine the effects of management control systems on the firm sustainability of textile and apparel businesses in Thailand. Management control systems are the main variable of the study, while organisational renewal, management development, business excellence, and firm sustainability are the outcome variables of the study. In this study, 186 textile and apparel businesses in Thailand compose the study sample. A mail survey questionnaire was used for data collection. Additionally, structural equation modelling is utilised to test the research relationships. The results show that management control systems positively impact organisational renewal and firm sustainability. In addition, organisational renewal positively affects management development, business excellence, and firm sustainability. Both management development and business excellence positively influence firm sustainability. However, it is found that management control systems are not related to management development and business excellence. In summary, management control systems can help firms survive and sustain themselves in highly variable environments. To gain a sustainable competitive advantage, superior performance, and long-term sustainability, firms' executives can pay attention to the development, utilisation, maintenance, and improvement of management control systems. To verify and expand the current study, future research needs to collect data from different populations or larger populations and employ other statistical techniques, such as regression analysis, partial least squares, and path analysis to prove the generalisability of the study.
\end{abstract}

(C) Asian Academy of Management and Penerbit Universiti Sains Malaysia, 2017. This work is licensed under the terms of the Creative Commons Attribution (CC BY) (http://creativecommons. org/licenses/by/4.0/). 
Keywords: management control system, organisational renewal, management development, business excellence, firm sustainability

\section{INTRODUCTION}

In highly rigorous, changing markets and environments, success, stability, growth, survival, and sustainability are needed to do business. Firms have attempted to create, implement, utilise, maintain, and improve their valuable strategies and techniques for competing against competitors. Excellent information and data can help firms conduct effective decision making via useful strategies and techniques to build and gain a sustainable competitive advantage. It also helps promote and achieve superior performance and profitability in these markets and environments. To succeed in competitive markets and environments, strategic management accounting is a significant determinant of firms' competitiveness and business outcomes. Strategic management accounting can produce information and data through the management accounting approach and method implementation to aid decision making to support firms' business success (Cadez \& Guilding, 2012). In the existing literature, management control systems are one of the strategic management accounting techniques. Strategic management accounting is a key driver for successfully doing business. Firms with efficient management control systems can effectively adjust themselves to current and future situations and circumstances. Such firms can critically develop and improve their operations, practices, and activities. They can fulfil customer needs and market requirements; obtain competitive competencies, capabilities and potentialities; and markedly increase their financial and non-financial performance.

As a reaction to more competitive and uncertain market environments, management control systems can be a strategic valuable management accounting approach and method to enhance firms' ability to renew their organisational operations, develop their management activities, increase their business excellence, and achieve longterm sustainability. A management control system is defined as a management tool that allows the planning, budgeting, analysing, measuring, and evaluating of useful accounting and financial information for proper decision making (Durendez, Ruiz-Palomo, Garcia-Perez-de-Lema, \& Dieguez-Soto, 2016). It is essential for fostering firms' decision making to realise a sustainable competitive advantage and achieve increased firm performance. Firms with a successful management control system implemented can develop a guideline for doing business and a direction for adjusting their employees' behaviours towards organisational objectives, goals, and purposes. While firms have achieved management control system effectiveness, it is possible for them to survive and sustain themselves over the long term and in 
complex competitive situations. In addition, management control system refers to a facilitating mechanism in the execution of firms' strategies that encourages broad employee engagement in the management process as a means of accomplishing both individual and managerial objectives (Jordao, Souza, \& Avelar, 2014). It is a means of gaining a competitive position and a focus on their management objectives. Firms can utilise management control systems to enhance their goal achievement and promote organisational success. Additionally, management control systems are considered important for creating business opportunities under the current and future competitive environments. Management control systems tend to positively affect organisational renewal, management development, business excellence, and firm sustainability. It is likely to determine, drive, and explain the changing level of organisational renewal, management development, business excellence, and firm sustainability.

In this study, textile and apparel businesses in Thailand compose the sample of the study because they are an important part of the Thai economy, including employment, national incomes, country development, and growth promotion. In 2016 , the value of those businesses were $3 \%$ of the total Thai exports, approximately USD6.8 billion, and $1.5 \%$ of employment in manufacturing, approximately 0.6 million persons (Thailand Textile Institute, 2017). Thailand is one of the few countries in the world that can supply the complete textile industry chain from upstream to midstream and downstream, and from petrochemical and natural fibre production to fabric and textiles. These businesses cover all the methods of the design, production, and sale of apparel, home textiles, and technical textiles, which are textiles used primarily for functional purposes by industry. To achieve their businesses' survival and sustainability in the long term, a valuable approach and method to help textile and apparel businesses meet their objectives, goals, and purposes is needed to encourage further innovation, modernise technology for greater efficiency, and improve the skills and competencies of their businesses. Accordingly, management control systems can be one of the most valuable approaches and methods that can be used to support these businesses in their competition against competitors and in their efforts to gain entry to markets in both the national and international environments. Accordingly, textile and apparel businesses in Thailand are considered an appropriate study sample.

This study attempts to investigate the effects of management control systems on organisational renewal, management development, business excellence, and firm sustainability. The objective of this study is to examine the influence of management control systems on the firm sustainability of textile and apparel businesses in Thailand. Here, firm sustainability refers to adopting business strategies, techniques, and activities that meet the needs of firms and their stakeholders 
today while protecting and enhancing the human and natural resources and assets that will be needed in the future (Karkoulian, Assaker, \& Hallak, 2016). Firm sustainability is measured by how effectively firms do business and continuously perform their operations in the current, future and long-term time periods. The key research question is how management control systems lead to firm sustainability. The specific research questions are as follows:

1. How are management control systems connected to organisational renewal, management development, and business excellence?

2. How does organisational renewal relate to management development, business excellence, and firm sustainability?

3. How does management development affect firm sustainability?

4. How does business excellence influence firm sustainability?

In the remainder of this study, the relevant literatures regarding management control systems and other related issues and their consequences are reviewed. In addition, the hypothesis development is identified, and the research methods are provided. The results and discussions are presented, and the limitations of the study, implications for theory and management, directions for future research, and conclusions of the study are provided.

\section{LITERATURE REVIEW AND HYPOTHESIS DEVELOPMENT}

A management control system is a firm's capability to use accounting and financial information through its management accounting system for proper decision making to achieve a sustainable competitive advantage and realise improved performance. A management control system is a source of firms' competitive advantage according to the theory of the resource-based view (RBV) of firms (Barney, 1991). The sources of firms' competitive advantage relating to RBV include resources and capabilities that have specific characteristics, namely value, rarity, lack of imitators, and irreplaceability. Successful management control system implementation is positively related to a firm's continuous success, stability, growth, survival, and sustainability in current and future environments, situations, and conditions. Hence, management control systems become a strategic business tool in helping firms survive and sustain themselves while doing business. It is a key determinant of firms' sustainability in the future and for long-term operations. In this study, management control systems are the main variable, while organisational renewal, management development, business excellence, and firm profitability are 
the consequent variables of the study. Thus, the research relationships of these variables are discussed and hypothesised. The conceptual model presents the aforementioned relationships, as shown in Figure 1.

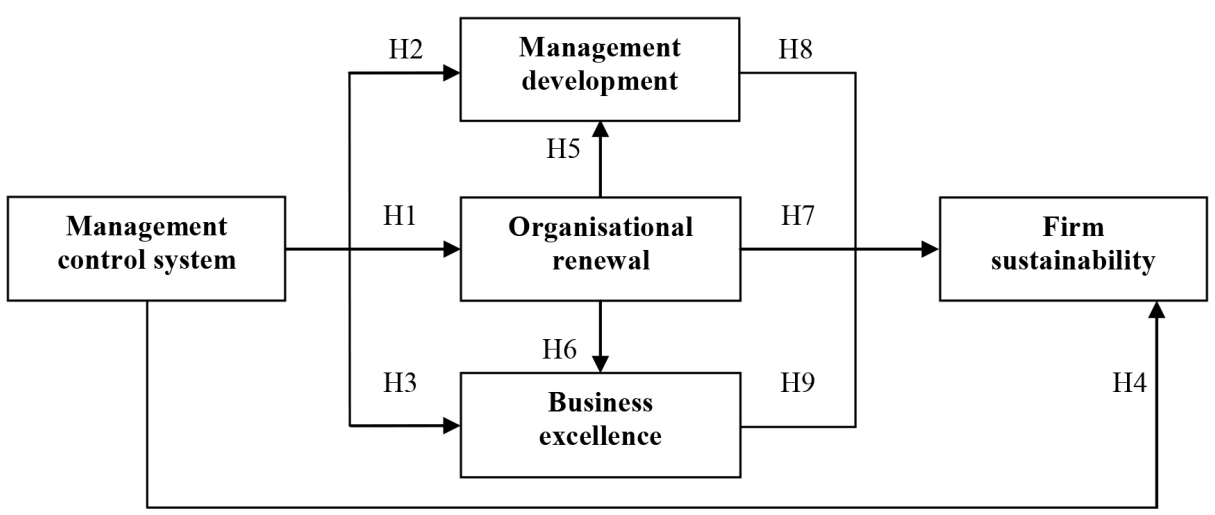

Figure 1. The conceptual model of the relationships between management control systems and firm sustainability

\section{Management Control System}

A management control system is a key dimension of strategic management accounting, and it plays a significant role in determining firms' competitive advantage and performance. It is a strategic valuable business tool, which can be used to enhance firms so they continuously achieve survival and sustainability in their future operations over the long term. Here, a management control system refers to a management tool that allows for the planning, budgeting, analysing, measuring, and evaluating of useful accounting and financial information for proper decision making to realise sustainable competitiveness and achieve increased performance (Durendez et al., 2016). Management control systems encourage firms to effectively respond to customer desires and market expectations, efficiently adapt to organisational operations, outstandingly develop management activities, excellently improve business practices, and critically achieve firm sustainability. Management control systems are essential for fostering an integration of organisational objectives and employee behaviours that fit with business environments, conditions and situations. In the existing literature, management control systems comprise formal controls (diagnostic and interactive controls) and informal controls (belief and behaviour controls) (Kallunki, Laitinen, \& Silvola, 2011). Formal controls focus on rules, performance evaluation, reward criteria, and budgeting systems to control results through feedback and feed forward 
loops, while informal controls emphasise beliefs, shared values, norms, cultures, traditions, and self-control (Lueg \& Radlach, 2016). Both of these controls can direct employees' behaviours and attentions towards organisational objectives, goals, and purposes. Good direction is a potential guideline for promoting desirable employee behaviours and achieving firms' performance goals. Firms with successful management control system implementation can achieve longterm sustainability in rapidly changing competitive markets and environments. These firms are likely to maintain outstanding levels of performance and achieve sustainability in conducting future business.

In addition, management control systems are a facilitating mechanism in the execution of firms' strategies, which are used to encourage broad employee engagement in the management process as a means of accomplishing both individual and managerial objectives (Jordao et al., 2014). Management control systems can provide useful information for the execution of managers' jobs, duties, and functions, and can assist firms to develop and maintain their patterns of behaviours (Langevin \& Mendoza, 2013). Management control systems are intended to motivate managers to ensure that organisational objectives are accomplished. Under the management control system, firms allow their managers to negotiate their objectives, resource requirements, and organisational results. Management control systems can help managers make the right decisions by aligning managers' objectives with the firms' goals by taking corrective actions. Management control systems support managers in their control of information as a tool for managing uncertainty and enhancing flexibility. Then, management control systems seem to motivate the effective behaviours of firms' managers and employees, which can drive them to achieve their goals. Also, a management control system is defined as a technique and a process used to achieve goal congruence, which may be designed for all levels of behavioural influences (Malmi \& Brown, 2008). Management control systems include performance evaluation as a method to focus on a process of measuring, evaluating, and rewarding performance and the socialisation of organisational members to emphasise an acquisition of values, attitudes, skills, and knowledge that promotes goal congruence among organisational members (Mahama, 2006). Management control systems provide a combination of control mechanisms that lead to an attainment of firms' goals. Hence, firms can apply management control systems to promote the firms' renewal, development, and excellence in an organisation and achieve the firms' performance, survival, and sustainability. Accordingly, management control systems are likely to help firms achieve better performance than their competitors and realise longer sustainability than their competitors. Thus, management control systems are likely to have a positive relationship with organisational renewal, management development, 
business excellence, and firm sustainability. Management control systems positively lead to the aforementioned outcomes. Therefore,

H1: Management control systems are positively related to organisational renewal.

H2: Management control systems are positively related to management development.

H3: Management control systems are positively related to business excellence.

H4: Management control systems are positively related to firm sustainability.

\section{Organisational Renewal}

Organisational renewal is a key outcome of management control system implementation (Poskela \& Martinsuo, 2009). Firms with effective management control systems can achieve superior organisational renewal. In this study, organisational renewal is defined as a managerial process used to modify and replace firms' current business models to address emerging environmental opportunities and risks for long-term survival, prosperity, and sustainability (Schmitt, Barker, Raisch, \& Whetten, 2016). Organisational renewal is considered a recursive interaction between environmental drivers and their strategic adaptation through utilising their competencies, capabilities, resources, and assets. Organisational renewal comprises an understanding of environmental situations, learning, and integrating firms' knowledge and experience, adapting firms' resources and capabilities to fit with and compete against the environments, responding to customer needs and market requirements, and achieving firms' long-term sustainability. Firms with outstanding organisational renewal can promote management development, increase business excellence, and create sustainability. Such firms are likely to develop efficiently, build effective excellence, and achieve a critical sustainability. In addition, organisational renewal refers to a set of activities that firms undertake to alter their resource use patterns and strategic actions in order to improve their overall performance (Ravasi \& Lojacono, 2005). Organisational renewal enhances firms' ability to search for a more favourable combination of resources and capabilities; transform their strategy, structure, systems, and culture to meet organisational objectives, goals and purposes; and foster proactive behaviours across the organisation by increasing environmental hostility and deteriorating competitive positions.

In turbulent environments, organisational renewal is an evolutionary process associated with promoting, accommodating, and utilising new knowledge 
and innovative behaviours to change firms' core competencies so that they are congruent with environmental conditions (Hopkins, Mallette, \& Hopkins, 2013). Organisational renewal entails a quantum shift in strategic thinking as organisations strive for a sustainable competitive advantage, superior performance, and longterm sustainability. Organisational renewal highlights the encouragement of firms' employees across the organisation to engage in dynamic activities of continuous learning and innovation. Firms with efficient organisational renewal tend to create an environment that supports intensive communication in real time, emphasises a reduction in uncertainty through experimentation and learning, and links current projects to a future with predictable and time-paced intervals (Lester \& Parnell, 2002). Greater organisational renewal is positively related to firms' development, excellence, and sustainability. Moreover, firms can build management development, improve business excellence, and increase corporate sustainability. Additionally, organisational renewal refers to a firm's dynamic organisational capability to continuously create, manage, and coordinate its knowledge and resources for improving sustainable performance (Junell \& Stahle, 2011). Organisational renewal enhances firms' abilities to shift over time from strategy formulation, knowledge processes, and organisational routines. Under conditions of organisational renewal, firms seem to focus on adjusting and responding to changing environments and circumstances through maintenance, adaptation, and innovation. Hence, firms can survive and sustain themselves in these environments and circumstances. Based on the previous discussion, organisational renewal is considered important for helping firms achieve and maintain great business outcomes. Thus, it organisational renewal is likely to determine, drive, and explain these outcomes. Organisational renewal tends to have a positive effect on management development, business excellence, and firm profitability. Therefore,

H5: Organisational renewal is positively related to management development.

H6: Organisational renewal is positively related to business excellence.

H7: Organisational renewal is positively related to firm sustainability.

\section{Management Development}

Management development is a sequence of implementing a management control system and providing organisational renewal (Sisaye, 2011). Greater management development arises from better management control system implementation and the greater application of organisational renewal under dynamically changing environments and conditions. Furthermore, both management control systems and organisational renewal play significant roles in determining, driving, and explaining management development. Here, management development is 
defined as an expansion of employees' abilities and capacities using the roles and processes of firms' overall competencies and capabilities (Suutari \& Viitala, 2008). Management development comprises three approaches and methods, namely, formal training and education, mentoring and special assignments, and self-help activities (Watson, 2008). Management development can rapidly move firms' employees' behaviours by utilising their resources and assets to meet the firms' objectives, goals, and purposes that create a competitive advantage, promote firm performance, and support long-term sustainability. Firms with outstanding management development can build competitiveness, realise strong performance and profitability and achieve success, growth, survival, and sustainability in rapidly changing competitive markets and environments. In addition, management development can continuously improve firms' operations, practices and activities and increase firms' long-term prospects (Mulili \& Wong, 2011). Management development provides a process that firms adopt in planning intervention strategies and techniques that enhance their organisational effectiveness and their employees' well-being by using the firms' competencies, capabilities, resources, assets, and potentialities and supporting from firms' executives' capacities and abilities. Hence, management development tends to have a positive influence on firm sustainability.

To successfully address competitive markets and environments, management development provides direction to firms' operations that enables them to accomplish their objectives and develop employees' careers in ways that encourage employees to achieve their goals (Kang, Shen, \& Xu, 2015). Successful management development tends to relate to great business outcomes. It can directly lead to firms' growth, ultimate survival, and long-term sustainability in a very competitive marketplace. Accordingly, management development is positively related to firm sustainability. Moreover, management development is a potential determinant that supports firms' sustainability (Pless, Maak, \& Stahl, 2012). Management development continuously improves firms' working conditions, situations and well-being, which are circumstances that can help create business opportunities, reduce organisational uncertainties and risks, create a competitive advantage, and build valuable outcomes in the current, future and long-term environments. Management development becomes an effective dynamic capability of firms that enhances their ability to survive and sustain themselves in highly variable situations. Thus, management development is likely to relate to firm sustainability. Management development positively affects firm sustainability. Therefore,

H8: Management development is positively related to firm sustainability. 


\section{Business Excellence}

In the existing literature, management control systems are a key driver of firms' business excellence. Additionally, business excellence is a significant outcome of management control system implementation (Doeleman, Have, \& Ahaus, 2012). Here, business excellence refers to the continuous improvement of all key processes, creativity and innovation, work conditions, teamwork, and organisational culture (Zdrilic \& Dulcic, 2016). Business excellence emphasises a commitment to achieving results without re-work, readiness to take on responsibility, continuous learning, and improvement and simplicity of operations, practices and activities. Business excellence can continuously improve values important for customers and stakeholders, such as customer satisfaction, employee satisfaction, and beneficial impacts on society (Metaxas \& Koulouriotis, 2014). Business excellence also increases organisational efficiency and employee learning and contributes to organisational sustainability. Firms with great business excellence tend to develop organisational operations that meet or exceed the expectations of all their stakeholders. Greater business excellence enhances firms' ability to achieve longer sustainability in highly turbulent competitive markets and environments. To achieve business excellence, firms are likely to develop a results orientation, a customer focus, leadership and a constancy of purpose, management through processes and facts, people development and involvement, continuous learning, innovation and improvement, partnership development, and a public responsibility (Dubey, 2016). Accordingly, business excellence ultimately leads to superior success, survival, and sustainability. Business excellence has a positive relationship with firm sustainability.

Business excellence is an important determinant of sustainable competitive advantage and superior performance (Escrig \& de Menezes, 2015). Business excellence can optimise firms' performance and minimise possibilities of mistakes through the use of best practices for firms' techniques, methods, processes, activities, and mechanisms. Firms with outstanding business excellence have promoted employee satisfaction, standardised internal operation processes, and increased process stability and capability (Mann, Adebanjo, Laosirihongthong, \& Punnakitikashem, 2011). Such firms can establish a good relationship with customers, suppliers, and stakeholders and comply with social, environmental, and safety issues. Hence, business excellence plays a significant role in determining firms' long-term sustainability in continuously changing competitive situations, conditions, and circumstances. In addition, business excellence arises from assessing firms' improvement efforts, diagnosing firms' overall performance management system, and identifying firms' strengths and opportunities for improvement (Asif et al., 2011). Business excellence encourages firms to achieve 
customer satisfaction, financial and market outcomes and product outcomes, and achieve sustainability over the long term. Thus, business excellence is positively related to firm profitability. Business excellence has a positive influence on firm sustainability. Therefore,

H9: Business excellence is positively related to firm sustainability.

\section{RESEARCH METHODS}

\section{Sample Selection Procedure and Data Collection}

In this study, all 934 textile and apparel businesses in Thailand, based on information from the Department of Business Development in Thailand's Ministry of Commerce, are part of the sample. Using accounting executives as key informants, a mail survey questionnaire was used for data collection. These key informants include chief financial officers, accounting directors, and accounting managers. The informants have the highest responsibility for the accounting functions and other related activities in an organisation. With regard to the mailed questionnaire, 35 surveys were undeliverable because some businesses had moved to unknown locations. Deducting the undeliverable surveys from the original 934 mailed, the valid mailing included 899 surveys from which 190 responses were received. Of the surveys completed and returned, 186 were usable. The effective response rate was approximately $20.69 \%$. The response rate for a mail survey with an appropriate follow-up procedure is considered acceptable if greater than $20 \%$, according to Aaker, Kumar, and Day (2001). To test for potential non-response bias, a comparison of the first and second wave data, as recommended by Armstrong and Overton (1977), is used. The results showed there were no statistically significant differences between the first and second groups at a 95\% confidence level with regard to firm age $(t=0.121, p>0.05)$, firm size $(t=0.127, p>0.05)$ and firm capital $(t=0.116, p>0.05)$.

\section{Measures}

All constructs were measured using a 5-point Likert scale $(1=$ strongly disagree to $5=$ strongly agree) except for firm age, firm size, and firm capital. Measurements of these constructs are self-developed from the existing literature, as shown in the Appendix. To develop the research measurements, this study has reviewed and studied definitions and explanations of the constructs and the study provides item scales for measuring them. Here, management control system is the main variable of the study and organisational renewal, management development, business 
excellence, and firm sustainability are the consequent variables of the study. A management control system refers to a management tool that allows for the planning, budgeting, analysing, measuring, and evaluating of useful accounting and financial information for proper decision making (Durendez et al., 2016). A five-item scale was developed to assess how firms approach diagnostic, interactive, belief, and behaviour controls through a usefulness of accounting and management information.

Organisational renewal refers to a managerial process used to modify and replace firms' current business models to address emerging environmental opportunities and risks (Schmitt et al., 2016). A four-item scale was established to measure how firms utilise their capabilities and resources to adapt to environmental hostility and competitive position and transform their strategy, structure, system, and culture to achieve organisational objectives. Additionally, management development refers to an expansion of employees' abilities and capacities by using the roles and processes of firms' overall competencies and capabilities (Suutari \& Viitala, 2008). A four-item scale was utilised to evaluate how firms adopt planned intervention strategies and techniques to enhance their organisational effectiveness and their employees' well-being by using their resources and supporting their executives' capacities. Likewise, business excellence refers to the continuous improvement of all key processes, creativity and innovation, work conditions, teamwork, and organisational culture (Zdrilic \& Dulcic, 2016). A four-item scale was developed to assess how firms perform their operations to meet or exceed expectations of all their stakeholders. Lastly, firm sustainability refers to adopting business strategies that meet the needs of firms and their stakeholders today while protecting and enhancing the human and natural resources that will be needed in the future (Karkoulian et al., 2016). A four-item scale was identified to measure how firms effectively do business and continuously perform their operations in the current, future, and long-term periods.

For the control variables, firm age was first measured by the number of years a firm has been in existence (Zahra, Ireland, \& Hitt, 2000). The number of years a firm has been in existence was measured by using a dummy variable of less than 10 years $=$ 0 and equal to or greater than 10 years $=1$. Second, firm size was measured by the number of employees in a firm (Arora \& Fosfuri, 2000). Firm size was measured based on the number of employees in a firm by using a dummy variable of less than 150 employees $=0$ and equal to or greater than 150 employees $=1$. Lastly, firm capital was measured based on the amount of money a firm has invested in doing business (Ussahawanitchakit, 2007). The amount of money a firm has invested in doing business was measured by using a dummy variable of less than 125 million $\mathrm{baht}=0$ and equal to or greater than 125 million baht $=1$. 


\section{Methods}

To verify the validity and reliability of the research instrument, factor analysis, item-total correlation, and Cronbach alpha coefficients are implemented to test the quality of the instrument. Factor analysis was implemented to assess the underlying relationships of a large number of items and to determine whether they can be reduced to a smaller set of factors. Thus, all factor loadings with values of $0.73-0.93$ are greater than the 0.40 cut-off and are statistically significant (Nunnally \& Bernstein, 1994). Next, discriminant power was utilised to gauge the validity of the measurements using item-total correlation. In the scale validity, item-total correlations with values of 0.75-0.92 are greater than 0.30 (Churchill, 1979). Lastly, the reliability of the measurements was evaluated using Cronbach alpha coefficients. In the scale reliability, Cronbach alpha coefficients with values of 0.83-0.92 are greater than 0.70 (Nunnally \& Bernstein, 1994). In this study, the scales of all measures express an accepted validity and reliability. Table 1 presents the results for factor loadings, item-total correlations, and Cronbach alphas used in this study.

Table 1

Results of measure validation

\begin{tabular}{lccc}
\hline Items & Factor loadings & Item-total correlation & Cronbach alpha \\
\hline Management control system (MC) & $0.86-0.93$ & $0.84-0.92$ & 0.92 \\
Organisational renewal (OR) & $0.84-0.91$ & $0.84-0.91$ & 0.90 \\
Management development (MD) & $0.73-0.86$ & $0.75-0.87$ & 0.84 \\
Business excellence (BE) & $0.80-0.82$ & $0.80-0.83$ & 0.83 \\
Firm sustainability (FS) & $0.82-0.88$ & $0.83-0.88$ & 0.86 \\
\hline
\end{tabular}

To test the effects of management control systems on the firm sustainability of textile and apparel businesses in Thailand, structural equation modelling (SEM) is considered an appropriate approach to investigate these relationships (Kianto, Saenz, \& Aramburu, 2017). SEM can fit the composite approach previously discussed and is also the safest option when estimating data from an unknown population. In this study, management control systems, organisational renewal, management development, business excellence, and firm sustainability are the variables of the study. 


\section{RESULTS AND DISCUSSION}

Table 2 presents the descriptive statistics and correlation matrix for all the variables. Multicollinearity might occur when the inter-correlation of each independent variable is more than 0.80 , which is a strong relationship (Hair, Black, Babin, \& Anderson, 2010). The correlations range from 0.16 to 0.78 at the $p<0.05$ level, which means that the possible relationships of the variables in the conceptual model could be tested. Thus, there are no substantial multicollinearity problems encountered in this study.

Table 2

Descriptive statistics and correlation matrix

\begin{tabular}{llllll}
\hline Variables & MC & OR & MD & BE & FS \\
\hline Mean & 4.20 & 3.85 & 3.99 & 4.00 & 3.98 \\
Standard deviation & 0.59 & 0.48 & 0.58 & 0.59 & 0.63 \\
Management control system & & & & & \\
Organisational renewal & $0.78^{* * *}$ & & & & \\
Management development & 0.21 & $0.26^{* *}$ & & & \\
Business excellence & 0.16 & $0.33^{* * *}$ & $0.76^{* * *}$ & & \\
Firm sustainability & $0.31^{* * *}$ & $0.44^{* * *}$ & $0.75^{* * *}$ & $0.77^{* * *}$ & \\
\hline
\end{tabular}

Note: $* * p<0.05, * * * p<0.01$

Table 3 presents the results of the path coefficients and the hypothesis testing of the research relationships. A summary of the management control system-firm sustainability relationship is shown in Figure 2. In this study, the goodness-offit of the models, including the goodness-of-fit index (GFI), the comparative fit index (CFI), the incremental fit index (IFI), and the root mean square error of approximation (RMSEA) are considered (Herda \& Lavelle, 2012). This study shows that the initial test of the measurement model resulted in a good fit with the data $(\mathrm{CFI}=0.96$; GFI $=0.95$; IFI $=0.93$; RMSEA $=0.04)$. First, CFI values always lie between 0 and 1 , and values over 0.90 indicate a relatively good fit (Bentler, 1990). Second, GFI value is an index that ranges from 0 to 1 , and a value over 0.90 indicates a relatively good fit (Byrne, 1998). Third, IFI values exceeding 0.90 indicate a relatively good fit (Kline, 1998). Lastly, a RMSEA value of less than 0.05 indicates a close fit and less than 0.08 suggests a marginal fit (Bollen \& Long, 1993). 
Table 3

Results of path coefficients and hypothesis testing

\begin{tabular}{lllll}
\hline Hypotheses & Relationships & Coefficients & t-value & Results \\
\hline H1 & MC $\rightarrow$ OR & $0.91^{* * *}$ & 15.14 & Supported \\
H2 & MC $\rightarrow$ MD & 0.08 & 0.52 & Not supported \\
H3 & MC $\rightarrow$ BE & 0.01 & 0.02 & Not supported \\
H4 & MC $\rightarrow$ FS & $0.11^{*}$ & 1.63 & Supported \\
H5 & OR $\rightarrow$ MD & $0.12^{*}$ & 1.79 & Supported \\
H6 & OR $\rightarrow$ BE & $0.24^{* *}$ & 3.63 & Supported \\
H7 & OR $\rightarrow$ FS & $0.18^{*}$ & 1.87 & Supported \\
H8 & MD $\rightarrow$ FS & $0.43^{* * *}$ & 6.18 & Supported \\
H9 & BE $\rightarrow$ FS & $0.55^{* * *}$ & 7.76 & Supported \\
\hline
\end{tabular}

Note: $* p<0.10, * * p<0.05, * * * p<0.01$

In this study, management control systems are a key determinant of organisational renewal and firm sustainability. Management control systems are positively related to organisational renewal $(\mathrm{b}=0.91, p<0.01)$ and firm sustainability $(\mathrm{b}=0.11$, $p<0.10)$. In the existing literature, management control systems play a significant role in determining, driving, and explaining both organisational renewal and firm sustainability. Management control systems are a management tool that allows for the planning, budgeting, analysing, measuring, and evaluating of useful accounting and financial information for proper decision making to realise sustainable competitiveness and achieve increased performance (Durendez et al., 2016). Management control systems are considered essential for fostering an integration of organisational objectives and employee behaviours that fit with business environments, conditions, and situations. Additionally, management control systems are a facilitating mechanism for firms' strategies because they encourage broad employee engagement in the management process that accomplishes both individual and managerial objectives (Jordao et al., 2014). Firms with an effective management control system can motivate effective behaviours in their managers and employees that can drive managers and employees to achieve their goals. Management control systems can affect organisational renewal efficiency and build long-term sustainability. However, management control systems have no effects on management development $(\mathrm{b}=0.08, p<0.61)$ and business excellence $(\mathrm{b}=0.01, p<0.99)$. Management control systems do not relate to either of them, but it does seem to have an indirect influence on management development and business excellence. According to the research results, organisational renewal is a mediator of the management control system-management development relationship and the management control system-business excellence relationship. 
Additionally, management control systems have a positive impact on organisational renewal and firm sustainability, but management control systems have no influence on management development and business excellence. Therefore, $\mathrm{H} 1$ and $\mathrm{H} 4$ are supported, but $\mathrm{H} 2$ and $\mathrm{H} 3$ are not.

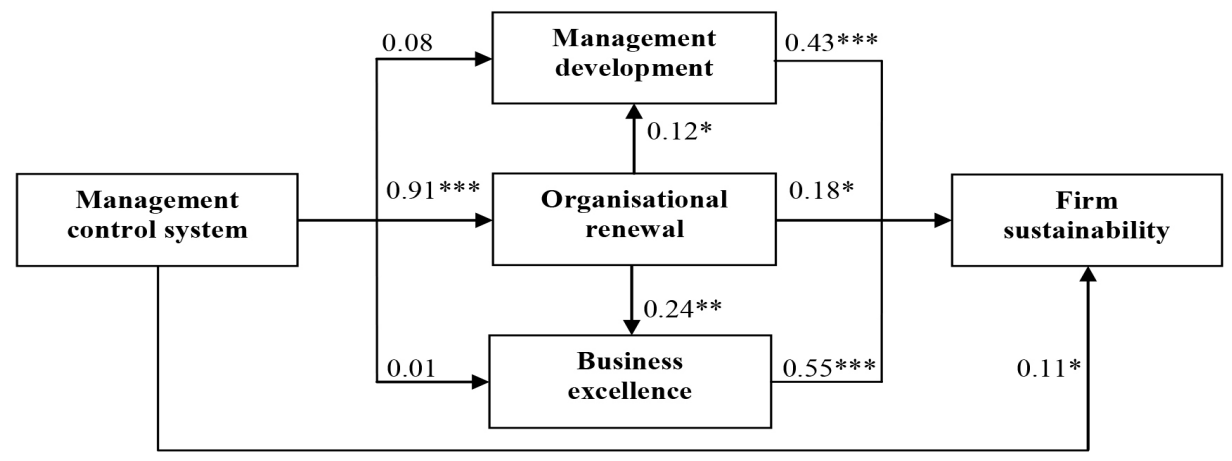

Figure 2. A summary of the management control system-firm sustainability relationship Notes: $* p<0.10 ; * * p<0.05 ; * * * p<0.01 ; \mathrm{CFI}=0.96$; GFI $=0.95$; IFI $=0.93$; RMSEA $=0.04$

Organisational renewal is an important driver of management development, business excellence, and firm sustainability. It positively affects management development $(b=0.12, p<0.10)$, business excellence $(b=0.24, p<0.05)$, and firm sustainability $(\mathrm{b}=0.18, p<0.06)$. In highly rigorous competitive markets and environments, organisational renewal is a managerial process for modifying and replacing firms' current business models to address emerging environmental opportunities and risks for long-term survival, prosperity, and sustainability (Schmitt et al., 2016). Organisational renewal enhances firms' abilities to search for a more favourable combination of resources and capabilities; transform their strategy, structure, systems, and culture to meet organisational objectives, goals and purposes; and foster proactive behaviours across the organisation by increasing environmental hostility and deteriorating competitive positions. Firms with successful organisational renewal can promote management development, increase business excellence and achieve their sustainability. Such firms tend to have outstanding management excellence, effective business excellence, and long-term sustainability. Thus, organisational renewal is positively related to the aforementioned consequences. Therefore, H5-H7 are supported.

In addition, management development has a significant effect on firm sustainability. It positively influences firm sustainability $(b=0.43, p<0.01)$. Management development expands employees' abilities and capacities by using the roles and processes of firms' overall competencies and capabilities (Suutari \& Viitala, 
2008). Management development can rapidly move firms' employees' behaviours by utilising the firms' resources and assets to meet employees' objectives, goals, and purposes to create a competitive advantage, promote firm performance, and support long-term sustainability. Hence, management development positively supports firm sustainability. To achieve firms' sustainability in the future and over the long term, firms need to provide management development by adopting planned intervention strategies and techniques that enhance their organisational effectiveness and their employees' well-being. More management development leads to longer sustainability. Therefore, $\mathrm{H} 8$ is supported.

Similarly, business excellence is positively related to firm sustainability $(b=0.55$, $p<0.01$ ). Business excellence focuses on the continuous improvement of all key processes, creativity and innovation, work conditions, teamwork, and organisational culture (Zdrilic \& Dulcic, 2016). Business excellence emphasises a commitment to achieving results without re-work, a readiness to take on responsibility, continuous learning, and the improvement and simplicity of operations, practices, and activities. Business excellence can optimise firms' performance and minimise the possibility of mistakes through the best practices of firms' techniques, methods, processes, activities, and mechanisms. Business excellence explicitly creates value for customers and stakeholders, standardises internal operation processes and increases process stability and capability (Mann et al., 2011). Accordingly, firms can obtain superior performance and achieve success, survival, and sustainability. Thus, business excellence has a significant influence on firm sustainability. Business excellence definitely determines firm sustainability. Therefore, H9 is supported.

\section{CONTRIBUTIONS AND DIRECTIONS FOR FUTURE RESEARCH}

\section{Theoretical Contributions and Limitations and Directions for Future Research}

This study confirms that management control systems are considered a key source of competitive and performance accounting, according to the RBV theory of the firms. In this study, management control systems are a valuable capability of firms. Successful management control systems have a significant influence on business outcomes. To verify and expand the current study, future research may need to do more literature reviews in order to investigate the effects of management control systems on both management development and business excellence. In addition, future research may need to search for dimensions and components of management control systems and test the influences of each dimension on the possible consequences. To prove the generalisability of the study, future research 
may need to collect data from different populations or larger populations and use a comparative study to verify the research relationships. A comparative study of different industries and different countries may also be considered in order to increase the generalisability of the study. Likewise, future research may employ a regression analysis, path analysis, and partial least squares to examine these relationships.

\section{Managerial Contribution}

According to the research results, management control systems are considered important to help firms gain a sustainable competitive advantage, achieve increased profitability, and improved performance and realise success, stability, growth, survival, and sustainability over the long term. Management control systems are a key determinant of firm sustainability. Management control systems play a significant role in driving and explaining firms' growth, survival, and sustainability. Thus, firms need to pay attention to creating, developing, improving, and maintaining the management control system in an organisation. Successful management control system implementation supports firms' abilities to increase their sustainability. In addition, firms need to motivate their employees' participation to join the firm's management control system. Firms also need to support employees' resources, capability, assets, and potentialities for the implementation of management control systems. Thus, firms can use a management control system as a strategic business approach and method to drive the firms' survival and sustainability in rapidly changing competitive markets and environments.

\section{CONCLUSION}

Management control systems are a significant driver of business outcomes. Thus, this study attempts to investigate the relationships between management control systems and firm systems. Here, this study aims at examining the influences of management control systems on the firm sustainability of textile and apparel businesses in Thailand. Management control systems, organisational renewal, management development, business excellence, and firm sustainability are the variables of the study. The results indicate that management control systems have a positive influence on organisational renewal and firm sustainability. Management control systems are essential for fostering an integration of firms' objectives and employee behaviours that fit with business environments and encourage broad employee engagement in the management process. Management control systems can efficiently provide organisational renewal and achieve firms' long-term sustainability through the effective behaviours of their managers and 
employees. In addition, organisational renewal positively leads to management development, business excellence, and firm sustainability. Organisational renewal is a managerial process for modifying firms' current business models to address emerging environmental opportunities and risks, provide more favourable combination of resources, transform strategies to reach firms' goals, and target proactive behaviours. These behaviours deteriorate competitive positions for promoting management development, business excellence, and firm sustainability. Similarly, both management development and business excellence positively affect firm sustainability. Management development can move employees' behaviours by utilising firms' resources to achieve their sustainability, while business excellence can minimise the possibility of mistakes by creating value for to stakeholders through standardised internal operations and increased process capability in order to enhance firms' sustainability. Accordingly, firms need to develop, maintain, and improve their management control system by utilising their resources, capabilities, and assets and implementing the management control system in the organisation by providing effective collaboration between managers and employees. Verifying and expanding the current study, future research needs to do more literature reviews, search for dimensions of management control system, collect data from different populations or larger populations, and employ a regression analysis, path analysis, or partial least squares to test the research relationships. 


\section{APPENDIX}

\section{Measurement of all variables}

Items

Firm sustainability (FS)

1. We have confidence that firms will be able to do business and expand their operations, practices and activities in the future and for the long term.

2. Our sales and market share have continuously grown compared with previous business operations from the past to the present.

3. We have outstandingly gained a return on investment and continuously achieved better profitability than our competitors.

4. We have created technical and administrative innovations in the organisation that can help firms compete against competitors and address highly rigorous competitive environments in the present and future.

Management control system (MC)

1. We believe that best management control systems can enhance firms' abilities to increase business opportunities, create a sustainable competitive advantage, achieve superior performance, and achieve survival and sustainability over the long term.

2. We use both formal and informal controls as guideline mechanisms to define, determine, and drive firms' operations, practices, and activities.

3. We can provide diagnostic and interactive controls, including rules, performance evaluations, reward criteria, and budgeting systems to control results through feedback and feed forward loops to move firms' business to meet organisational goals.

4. We can encourage employees to be aware of beliefs and behaviour controls via their beliefs, shared values, norms, cultures, traditions, and self-control.

Organisational renewal (OR)

1. We can modify and replace firms' current business models to address emerging environmental opportunities and risks for survival and sustainability.

2. We focus on a recursive interaction between environmental drivers and their strategic adaptation by utilising capabilities and resources, and assets.

3. We promote, accommodate and utilise new knowledge and innovative behaviours to change firms' core competencies so that they are congruent with environmental conditions.

4. We create an environment that supports intensive communication in real time, emphasise a reduction of uncertainty through experimentation and learning, and link current projects to a future with predictable and time-paced intervals. 
Appendix (continued)

Items

Management development (MD)

1. We can promote employees' abilities and capacities by using roles and processes derived from firms' overall competencies and capabilities.

2. We can develop firms' operations through formal training and education, mentoring, and special assignments and self-help activities.

3. We can move employees' behaviours to meet objectives, goals, and purposes that create a competitive advantage, promote employee performance, and support long-term sustainability.

4. We can adopt planned intervention strategies and techniques that enhance firms' organisational effectiveness and their employees' well-being.

Business excellence (BE)

1. We continuously improve all key processes, creativity and innovation, work conditions, teamwork, and organisational culture.

2. We achieve results without re-work and continuously learn and improve the simplicity of operations, practices, and activities.

3. We optimise firms' performance and minimise the possibility of mistakes through best practices of the firms' techniques, methods, processes, activities, and mechanisms.

4. We can provide organisational operations that meet or exceed the expectations of all stakeholders.

\section{REFERENCES}

Aaker, D.A., Kumar, V., \& Day, G.S. (2001). Marketing research. New York, NY: John Wiley \& Sons. https://doi.org/10.1509/jmkr.38.4.485.18905

Armstrong, J.S., \& Overton, T.S. (1977). Estimating non-response bias in mail surveys. Journal of Marketing Research, 14(3), 396-402. https://doi.org/10.2307/3150783

Arora, A., \& Fosfuri, A. (2000). Wholly-owned subsidiary versus technology licensing in the worldwide chemical industry. Journal of International Business Studies, 31(4), 555-572. https://doi.org/10.1057/palgrave.jibs.8490922

Asif, M., Searcy, C., Garvare, R., \& Asmad, N. (2011). Including sustainability in business excellence models. Total Quality Management, 22(7), 773-786. https://doi.org/1 $0.1080 / 14783363.2011 .585784$

Barney, J. (1991). Firm resources and sustained competitive advantage. Journal of Management, 17(1), 99-120. https://doi.org/10.1177/014920639101700108

Bentler, P. M. (1990). Comparative fit indices in structural models. Psychological Bulletin, 107(2), 238-246. https://doi.org/10.1037/0033-2909.107.2.238

Bollen, K.A., \& Long, J.S. (1993). Testing structural equation models. California: Sage Publications.

Byrne, B.M. (1998). Structural equation modelling with LISREL, Prelis and Simplis: Basic concepts, applications and programming. New Jersey: L. Erlbaum Associates. 
Cadez, S., \& Guilding, C. (2012). Strategy, strategic management accounting and performance: A configurational analysis. Industrial Management and Data Systems, 112(3), 484-501. https://doi.org/10.1108/02635571211210086

Churchill, G.A., Jr. (1979). A paradigm for developing better measures of marketing constructs. Journal of Marketing Research, 16(February), 64-73. https://doi. org/10.2307/3150876

Doeleman, H.J., Have, S.T., \& Ahaus, K. (2012). The moderating role of leadership in the relationship between management control and business excellence. Total Quality Management, 23(5), 591-611. https://doi.org/10.1080/14783363.2012.6 69935

Dubey, M. (2016). Developing an agile business excellence model for organizational sustainability. Global Business and Organizational Excellence, January/February, 60-71. https://doi.org/10.1002/joe.21656

Durendez, A., Ruiz-Palomo, D., Garcia-Perez-de-Lema, D., \& Dieguez-Soto, J. (2016). Management control systems and performance in small and medium family firms. European Journal of Family Business, 6(1), 10-20. https://doi.org/10.1016/j. ejfb.2016.05.001

Escrig, A.B., \& de Menezes, L.M. (2015). What characterizes leading companies within business excellence models? An analysis of "EFQM recognized for excellence" recipients in Spain. International Journal of Production Economics, 169, 362375. https://doi.org/10.1016/j.ijpe.2015.08.019

Hair, J.F., Black, W.C., Babin, B.J., \& Anderson, R.E. (2010). Multivariate data analysis: A global perspective (7th ed.). New Jersey: Pearson Prentice Hall. https://doi. org/10.1016/j.jmva.2009.12.014

Herda, D.N., \& Lavelle, J.J. (2012). The auditor-audit firm relationship and its effect on burnout and turnover intention. Accounting Horizons, 26(4), 707-723. https://doi. org/10.2308/acch-50181

Hopkins, W.E., Mallette, P., \& Hopkins, S.A. (2013). Proposed factors influencing strategic inertia/strategic renewal in organizations. Academy of Strategic Management Journal, 12(2), 77-94.

Jordao, R.V.D., Souza, A.A., \& Avelar, E.A. (2014). Organizational culture and postacquisition changes in management control systems: An analysis of a successful Brazilian case. Journal of Business Research, 67(4), 542-549. https://doi. org/10.1016/j.jbusres.2013.11.011

Junell, J., \& Stahle, P. (2011). Measuring organizational renewal capability: Case training service business. Competitiveness Review: An International Business Journal, 21(3), 247-268. https://doi.org/10.1108/10595421111134840

Kallunki, J., Laitinen, E.K., \& Silvola, H. (2011). Impact of enterprise planning systems on management control systems and firm performance. International Journal of Accounting Information Systems, 12(1), 20-39. https://doi.org/10.1016/j. accinf.2010.02.001

Kang, H., Shen, J., \& Xu, G. (2015). International training and management development policies and practices of South Korean MNEs in China. Thunderbird International Business Review, 57(3), 229-240. https://doi.org/10.1002/tie.21695 
Karkoulian, S., Assaker, G., \& Hallak, R. (2016). An empirical study of 360-degree feedback, organizational justice and firm sustainability. Journal of Business Research, 69(5), 1862-1867. https://doi.org/10.1016/j.jbusres.2015.10.070

Kianto, A., Saenz, J., \& Aramburu, N. (2017). Knowledge-based human resource management practices, intellectual capital and innovation. Journal of Business Research, 81, 11-20. https://doi.org/10.1016/j.jbusres.2017.07.018

Kline, R.B. (1998). Principles and practices of structural equation modeling. New York, NY: The Guilford Press.

Langevin, P., \& Mendoza, C. (2013). How can management control system fairness reduce managers' unethical behaviors? European Management Journal, 31(3), 209-222. https://doi.org/10.1016/j.emj.2012.12.001

Lester, D., \& Parnell, J.A. (2002). Aligning factors for successful organizational renewal. Leadership and Organization Management Journal, 23(2), 60-67. https://doi. org/10.1108/01437730210419189

Lueg, R., \& Radlach, R. (2016). Managing sustainable development with management control systems: A literature review. European Management Journal, 34(2), 158171. https://doi.org/10.1016/j.emj.2015.11.005

Mahama, H. (2006). Management control systems, cooperation and performance in strategic supply relationships: A survey in the mines. Management Accounting Research, 17(3), 315-339. https://doi.org/10.1016/j.mar.2006.03.002

Malmi, T., \& Brown, D.A. (2008). Management control systems as a package-opportunities, challenges and research directions. Management Accounting Research, 19(4), 287-300. https://doi.org/10.1016/j.mar.2008.09.003

Mann, R., Adebanjo, D., Laosirihongthong, T., \& Punnakitikashem, P. (2011). Awareness and impact of business excellence in Asia. Total Quality Management, 22(11), 1237-1258. https://doi.org/10.1080/14783363.2011.624772

Metaxas, I.N., \& Koulouriotis, D.E. (2014). A theoretical study of the relation between TQM assessment and sustainable business excellence. Total Quality Management, 25(5), 494-510. https://doi.org/10.1080/14783363.2013.867608

Mulili, B.M., \& Wong, P. (2011). Continuous organizational development (COD). Industrial and Commercial Training, 43(6), 377-384. https://doi. org/10.1108/00197851111160513

Nunnally, J.C., \& Bernstein, I.H. (1994). Psychometric theory. New York, NY: McGrawHill.

Pless, N.M., Maak, T., \& Stahl, G.K. (2012). Promoting corporate social responsibility and sustainable development through management development: What can be learned from international service learning programs? Human Resource Management, 51(6), 873-904. https://doi.org/10.1002/hrm.21506

Poskela, J., \& Martinsuo, M. (2009). Management control and strategic renewal in the front end of innovation. Journal of Product Innovation Management, 26(6), 671684. https://doi.org/10.1111/j.1540-5885.2009.00692.x

Ravasi, D., \& Lojacono, G. (2005). Managing design and designers for strategic renewal. Long Range Planning, 38(1), 51-77. https://doi.org/10.1016/j.lrp.2004.11.010 
Schmitt, A., Barker, V.L.III, Raisch, S., \& Whetten, D. (2016). Strategic renewal in times of environmental scarcity. Long Range Planning, 49(3), 361-376. https://doi. org/10.1016/j.lrp.2015.08.004

Sisaye, S. (2011). Ecological systems approaches to sustainability and organizational development: Emerging trends in environmental and social accounting reporting systems. Leadership and Organization Development Journal, 32(4), 379-398. https://doi.org/10.1108/01437731111134652

Suutari, V., \& Viitala, R. (2008). Management development of senior executives: Methods and their effectiveness. Personnel Review, 37(4), 375-392. https://doi. org/10.1108/00483480810877561

Thailand Textile Institute. (2017). Thai textile statistics 2016/2017. Retrieved 26 October 2017 from http://www.thaitextile.org/index.php/blog/2017/08/ news_20092017_07

Ussahawanitchakit, P. (2007). The influences of management capability on export performance of leather businesses in Thailand. Review of Business Research, $7(5), 1-10$.

Watson, S. (2008). Where are we now? A review of management development issues in the hospitality and tourism sector. International Journal of Contemporary Hospitality Management, 20(7), 758-780. https://doi.org/10.1108/09596110810897592

Zahra, S.A., Ireland, R.D., \& Hitt, M.A. (2000). International expansion by new venture firms: International diversity, mode of market entry, technological learning, and performance. Academy of Management Journal, 43(5), 925-950. https://doi. org/10.2307/1556420

Zdrilic, I., \& Dulcic, Z. (2016). Business excellence as a success factor for the performance of large Croatian enterprises. Management, 21(1), 145-165. 